\title{
MODEL KEPEMIMPINAN DALAM PEMBINAAN KARAKTER PESERTA DIDIK DI SMK NEGERI LABUANG KABUPATEN POLEWALI MANDAR
}

\author{
HAMSIAH DJAFAR \\ Fakultas Tarbiyah dan Keguruan UIN Alauddin Makassar \\ JI. HM. Yasin Limpo No. 36 Makassar \\ Email: djafar.cia@gmail.com
}

\begin{abstract}
:
This study aims to describe the leadership model in the character development of learners at SMK Negeri Labuang Polewali Mandar regency, including the leadership model of school principals in shaping the character of learners, the constraints faced in the character development of learners, as well as efforts made in the character development of learners in SMK Negeri Labuang. This research uses qualitative approach with case study design. The research location is SMK Negeri Labuang Polewali Mandar Regency. Laliko Village, Campalagian District, Polewali Mandar Regency, West Sulawesi Province. The data sources of this research are principals, vice principals, teachers, and teachers BK. Data were obtained through in-depth interviews, participant observation and documentation. The data analysis technique in this research is by: 1) data reduction (data reduction) that summarizes, chooses the main things, focus on the things that are important, sought the theme and pattern and verification of data on different data sources. remove unnecessary, 2) Presentation of data (data display) after the data is reduced. 3) data verification (conclution drawing verification) that is withdrawal conclusion by using source triagulation method that is data verification method at different source. The results of the analysis can be obtained by the model of leadership in the character development of learners in SMK Negeri Labuang Polewali Mandar regency has been implemented in accordance with the education system where, his leadership as headmaster of SMK Negeri Labuang, which adheres to democratic and occasionally authoritarian leadership model has applied professionally, and coaching in the formation of the character of learners with a democratic leadership model has been applied in the activities of learners either the curricular activities of subjects as well as extracurricular activities inside or outside school
\end{abstract}

Keywords: Leadership, Character Development, Learners

\section{PENDAHULUAN}

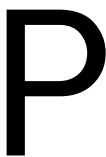
ada dewasa ini sasaran pendidikan adalah manusia. Pendidikan bermaksud membantu peserta didik untuk menumbuhkembangkan benih kemungkinan untuk menjadi manusia.

Dalam usahanya untuk bermasyarakat, maka manusia berkelompok atau memasuki sesuatu kelompok atau organisasi, juga demi mencapai sesuatu kepuasan lahir/batin serta peningkatan diri, Kelompok atau organisasi itu kemudian menjadi himpunan manusia dengan berbagai kelebihan dan kekurangannya 
masing-masing. Bila dalam organisasi tersebut kemudian ada yang sangat menonjol, dan diakui kelebihannya oleh anggota- anggota atau sebagian besar anggota-anggotanya, terutama dalam mempengaruhi dan menggerakkan usaha bersama dalam mencapai sesuatu tujuan yang telah ditetapkan, maka ia disebut pemimpin. Model atau proses untuk mempengaruhi serta menggerakkan orang lain atau sekelompok orang untuk mencapai sesuatu tujuan yang telah ditetapkan, disebut sebagai kepemimpinan (Gunawan, 2000: 123).

Dalam tulisan ini menggunakan organisasi sebagai sebuah lembaga pendidikan yaitu sekolah. Dalam konteks model kepemimpinan pendidikan, yang dimaksud dengan model yaitu pola atau acuan yang digunakan dalam menetapkan arah atau mendefinisikan dan menerapkan rencana strategi untuk mencapai tujuan sekolah dalam kemampuan kepemimpinan kepala sekolah dari realisasi semua program berdasarkan strategi sesuai dengan fungsi dan situasi yang dihadapi (Danim, 2008: 56).

Pemimpin adalah semua orang yang bertanggungjawab dalam proses perbaikan yang berada pada semua level kelembagaan pendidikan. Pada pemimpin pendidikan harus memiliki komitmen terhadap perbaikan mutu kualitas dalam fungsi utamanya. Oleh karena itu, fungsi-fungsi dari kepemimpinan pendidikan haruslah tertuju pada mutu atau kualitas belajar.

Sekolah adalah organisasi yang kompleks dan unit sehingga memerlukan tingkat koordinasi yang tinggi. Oleh sebab itu, sebagai pemimpin dalam sebuah organisasi sekolah (Kepala Sekolah), dapat dikatakan berhasil apabila tercapainya tujuan sekolah, serta tujuan dari individu yang ada di dalam lingkungan sekolah, harus bersama dan menguasai peranan orang tua dan hubungan kerja sama antara individu.

Model kepemimpinan merupakan norma perilaku yang diperlukan olehseorang pada saat orang tersebut mencoba mempengaruhi perilaku orang lain. Model kepemimpinan adalah suatu pola perilaku yang konsisten yang ditunjukkan oleh pemimpin dan diketahui pihak lain ketika pemimpin berusaha mempengaruhi kegiatan orang lain. Model kepemimpinan adalah pola tingkah laku atau strategi yang dikuasai oleh seorang pemimpin dalam proses mengarahkan dan mempengaruhi para pekerja.

Kemampuan kepemimpinan kepala sekolah merupakan faktor utama yang perlu segera dikembangkan. Saat ini saja sudah menunjukkan bahwa kemampuan kepala sekolah masih relatif rendah. Sebagai kepala sekolah cenderung hanya menangani masalah, administrasi, memonitor kehadiran guru, atau membuat laporan ke pengawas, dan belum menunjukkan peranan sebagai pemimpin yang professional (Danim, 2008: 14).

Berdasarkan pernyataan di atas, maka penulis merumuskan masalah sebagai berikut:

1. Bagaimanakah model kepemimpinan kepala sekolah di SMK Negeri Labuang 
dalam meningkatkan karakter peseta didik?

2. Bagaimana karakter peserta didik di SMK Negeri Labuang?

3. Kendala apa yang dihadapi dalam pembinaan peserta didik di SMKNegeri Labuang?

\section{TINJAUAN TEORETIS}

\section{Pengertian Kepemimpinan Kepala Sekolah \\ Kepemimpinan}

Kepemimpinan berkaitan dengan seni dan kemampuan mempengaruhi seseorang atau sekelompok orang untuk bertindak, Menurut Robbins (1998), kepemimpinan adalah kemampuan mempengaruhi suatu kelompok ke arah pencapaian tujuan (Danim, 2008: 3).

\section{Kepala Sekolah}

Kepala sekolah sebagai pemimpin pendidikan, fungsi utama kepala sekolah sebagai pemimpin pendidikan di suatu lembaga pendidikan (sekolah).Kepala sekolah adalah guru yang diberikan tugas tambahan untuk memimpin suatu sekolah yang diselenggarakan proses belajar-mengajar atau tempat terjadi interaksi antara guru yang memberi pelajaran dan murid yang menerima pelajaran (https://idwikipedia.org.wiki/Kepala sekolah).

\section{Hubungan Guru (Kepala sekolah) dengan Siswa}

Mendapatkan hasil belajar yang optimal, banyak dipengaruhi komponen-komponen belajar mengajar. Tapi di samping komponen pokok yang ada dalam kegiatan belajar-mengajar, ada faktor lain yang ikut mempengaruhi keberhasilan belajar siswa, yaitu soal hubungan antara guru dan siswa. Hubungan guru dengan siswa/anak didik di dalam proses belajar mengajar merupakan faktor yang sangat menentukan. Bagaimana baiknya bahan pelajaran yang diberikan, bagaimanapun sempurnanya metode yang digunakan, namun jika hubungan guru-siswa merupakan hubungan yang tidak harmonis, maka dapat menciptakan suatu hasil yang tidak diinginkan.

\section{Model Kepemimpinan Kepala Sekolah Kepemimpinan Otoriter}

Tipe kepemimpinan otoriter adalah paling banyak dikenal karena tergolong yang paling tua. Kepemimpinan ini menempatkan kekuasaan di tangan seseorang atau sekelompok kecil orang-orang yang disebut atasan sebagai penguasa atau penentu yang tidak dapat diganggu gugat, dan orang yang lain (bawahan) harus tunduk pada kekuatannya dibawah ancaman dan hukuman sebagai alat dalam menjalankan kepemimpinannya (monokrasi dan olograsi) (Gunawan, 2000: 220).

\section{Kepemimpinan Pseudo Demokratis}

Istilah pseudo berarti palsu. Maka pseudo demokratis berarti bukan i tidak 
demokratis. Gaya kepemimpinan seperti ini sebenarnya otokratis, tetapi dalam kepemimpinannya ia memberi kesan demokrtis. Seorang pemimpin bersifat pseudo-demokratis sering memakai "topeng" la pura-pura memperlihatkan sifat demokratis di dalam kepemimpinannya.la memberi hak dan kuasa kepada guru-guru untuk menetapkan dan memutuskan sesuatu, tetapi sesungguhnya ia bekerja dengan perhitungan.

\section{Kepemimpinan Bebas (Laissez Faire)}

Gaya kepemimpinan bebas atau Laissez Faire ini diartikan memberikan orang-orang berbuat sekehendaknya. Gaya kepemimpinan seperti ini sang pemimpin praktis tidak memimpin. Pemimpin seperti ini sama sekali tidak memberikan kontrol dan koreksi terhadap pekerjaan para bawahan atauanggotanya.

\section{Kepemimpinan Demokratis}

Gaya kepemimpinan demokratis ini adalah gaya kepemimpinan yang paling ideal. Pemimpin yang demokratis ini adalah pemimpin yang kooperatif dan tidak diktator. Dia selalu menstimulasi anggota-anggota kelompoknya untuk bekerja bersama-sama dalam mencapai tujuan bersama pula. Dalam tindakan dan usaha-usahanya, ia selalu berpangkal pada kepentingan dankebutuhan kelompoknya dan selalu mempertimbangkan kesanggupan serta kemampuan kelompoknya.

\section{Pengertian Karakter Peserta Didik}

Karakter berasal dari bahasa Latin character di dalam bahasa Arab disebut juga khuluq artinya watak, tabiat, budi pekerti, sifat-sifat kejiwaan dan akhlak. Secara terminologi (istilah) karakter adalah nilai-nilai perilakumanusia yang berhubungan dengan Tuhan Yang Maha Esa, diri sendiri, sesama manusia, lingkungan, dan kebangsaan, yang terwujud dalam pikiran, sikap, perasaan, perkataan, dan perbuatan berdasarkan norma-norma agama, hukum, tata krama, budaya dan adat istiadat.

\section{Faktor - Faktor Yang Mempengaruhi Karakter Peserta Didik}

Peserta didik bisa menjadi pribadi yang baik dan menjadi manusia yang berakhlak mulia tidak terlepas dari faktor-faktor yang mempengaruhinya. Banyak faktor yang membuat siswa mampu bertindak baik atau sebaliknya bertindak buruk. HeriGunawan menyebutkan bahwa faktor-faktor yang mempengaruhi pembentukan karakter ada 2 yaitu:

1. Faktor Intern

Ada beberapa faktor intern, di antaranya adalah:

a. Insting atau Naluri

b. Adat atau kebiasaan

c. Kehendak/Kemauan 
d. Suara batin atau suara hati y

e. Keturunan

2. Faktor Ekstern

a. Pendidikan

b. Lingkungan

Kendala Yang Dihadapi Dalam Pembinaan Karakter Peserta Didik

Beberapa kendala yang terjadi dalam pembinaan karakter peserta didik antara lain yaitu:

1. Tipe Kepemimpinan Guru

2. Gaya Guru yang Menoton

3. Kepribadian Guru

4. Pengetahuan Guru

5. Terbatasnya kesempatan guru untuk memahami tingkah laku peserta didik dan latar belakangnya.

6. PesertaDidik

7. Keluarga

8. Fasilitas

\section{METODOLOGI PENELITIAN}

Jenis dan Lokasi Penelitian

Penelitian ini adalah penelitian kualitatif yakni penelitian yang berlandaskan pada filsafat postpositivisme digunakan untuk meneliti pada kondisi obyek yang alamiah dimana peneliti adalah instrument (Creswell, 2010: 28).

Jenis penelitian ini adalah penelitian kualitatif. Bogdan dan Taylor mendefinisikan penelitian kualitatif sebagai penelitian yang menghasilkan data deskriptif berupa kata-kata tertulis atau lisan dan orang-orang dan perilaku yang dapat diamati (Moleong, 2002: 9).

Lokasi yang peneliti pilih dalam penelitian adalah SMK Negeri Labuang, Provinsi Sulawesi Bar at, Kabupaten Polewali Mandar, Kecamatan Campalagian, Desa Laliko.

\section{Pendekatan Penelitian}

Pendekatan yang digunakan dalam penelitian ini adalah:

a. Pendekatan Sosiologi, yaitu pendekatan yang berdasarkan situasi yang terjadi di masyarakat atau di lingkungan sekolah.

b. Pendekatan Psikologis, yaitu pendekatan yang berdasar pada tingkah laku seseorang.

\section{Sumber Data}

Sumber data dalam penelitian adalah subyek dari mana data diperoleh (Suharsimi, 2010: 172). Adapun yang dijadikan sumber data adalahmelakukan wawancara yang sesuai dengan instrumen penelitian terhadap Kepala Sekolah, 
Wakil Kepala Sekolah, guru-guru, dan guru BK di SMK Negeri Labuang

\section{Metode Pengumpulan Data dan Instrumen Penelitian}

Metode pengumpulan data menggunakan multi sumber bukti (triagulasi) artinya teknik pengumpulan data yang bersifat menggabungkan dari berbagai teknik data dan sumber data yang telah ada. Triagulasi teknik berarti peneliti menggunakan teknik pengumpulan data yang berbeda-beda untuk mendapatkan data dari sumber yang sama. Penulis akan menggunakan observasi partisipatif, wawancara mendalam, dan dokumentasi untuk sumber data yang sama secara serempak (Sugiyono. 2008: 83). Sedangkan instrumen yang digunakan adalah: 1) Panduan Observasi, 2) Panduan Wawancara, dan 3) Format Dokumentasi.

\section{Teknik Pengelolaan dan Analisis Data Teknik Pengelolaan Data}

Penelitian ini bersifat kualitatif yaitu data yang tidak menggunakan statistik hanya bersifat deskriptif dalam menganalisis data penulis menggunakan analisis data sebelum di lapangan serta menggunakan reduksi data (data reduction), penyajian data (data display) dan verifikasi data (conclusion drawing / verification):

1) Reduksi data (data reduction)

2) Penyajian data (data display)

3) Verifikasi data (conclusion drawing verification)

\section{Teknik Analisis Data}

Menurut Sugiyono dalam Bukunya yang berjudul Metode Penelitian Pendidikan (2015) mengartikan Analisis data yaitu suatu proses mencari dan menyusun secara sistematis data yang diperoleh dari hasil wawancara, catatan lapangan, dan dokumentasi, dengan cara mengkoordinasikan data kedalam kategori, menjabarkan kedalam unit-unit, melakukan sentesa, menyusun kedalam pola, memilih mana yang penting dan mana yang akan dipelajari, dan membuat kesimpulan sehingga mudah dipahami oleh diri sendiri maupun orang lain.

\section{HASIL PENELITIAN DAN PEMBAHASAN}

\section{Model Kepemimpinan Kepala Sekolah Dalam Membentuk Karakter Peserta Didik SMK Negeri Labuang.}

Dalam dunia pendidikan, pelaksanaan sejumlah teori, ide, maupun model kepemimpinan adalah bentuk sejauh mana implementasi hal tersebut berhasil dalam pelaksanaannya. Demikian juga dengan kepemimpinan Bapak Rudi Yunus, S.Pd. M.Pd., selaku kepala sekolah SMK Negeri Labuang, yang menganut model kepemimpinan demokratis dan sesekali otoriter dan sudah diterapkan secara profesional dan optimal. Selain mampu mengoperasionalkan peran, fungsi, serta tanggung jawab, tolak ukur penilaian keberhasilan kepemimpinan yang lain adalah model kepemimpinan yang digunakan. Model kepemimpinan demokratis tetap diprioritaskan sebagai dasar dalam memutuskan setiap kebijakan yang dibuat. 
Kepemimpinan ini, telah dijalankan oleh beliau selaku kepala sekolah SMK Negeri Labuang antara lain, musyawarah, adil, memberikan kebebasan berpikir dan berpendapat. Menurut beliau:

Pemimpin harus dapat menjadi yang terbaik dan mampumengendalikan, mengontrol, dan memberikan contoh yang baikkepada bawahannya. Sikap kepemimpinan yang otoriter terkadang juga diperlukan oleh seorang pemimpin dal am mengambil suatu keputusan selama keputusan tersebut baik bagi peningkatan lembaga pendidikan tersebut, akan tetapi tergantung bagaimana strategi pemimpin mengontrolnya agar pengambilan keputusan tidak dirasa otoriter dan dapat diterima oleh semua pihak tanpa ada rasa tekanan maupun tuntutan dari pemimpin (Rudi Yunus, Wawancara, Rabu, 06 Februari 2017).

\title{
Kendala Yang Dihadapi Kepala Sekolah, Guru-Guru dan Guru BK dalam Pembinaan Karakter Peserta Didik Di SMK Negeri Labuang
}

Dalam menerapkan nilai - nilai karakter pada peserta didik, kepala sekolah, guru - guru maupun guru BK SMK Negeri Labuang, terkadang menemui beberapa kendala atau hambatan, kendala ini, datangnya bisa dari peserta didik sendiri, tetapi terkadang juga karena adanya faktor lain misalnya kondisi lingkungan tempat tinggal peserta didik, orang tua peserta didik, bahkan dari pihak sekolah sendiri. Untuk mengetahui kendala apa saja yang dihadapi oleh Kepala Sekolah, Guru - guru maupun Guru BK SMK Negeri Labuang. Berikut pemaparan Rudi Yunus, S.Pd. M.Pd. selaku kepaia sekolah SMK Negeri Labuang tentang kendala yang dihadapi pada saat pembinaan karakter peserta didik.

\begin{abstract}
"Ada beberapa kendala yang sering kami hadapi dalam pembinaan karakter peserta didik di sekolah kami, diantaranya yaitu kedisiplinan, kejujuran, dan religiusnya, dimana kendala yang sering dihadapi oleh Bapak/Guru untuk menanamkan sikap religius kepada peserta didik yaitu peserta didik sulit diatur karena pengaruh lingkungan yang kurang baik. Saya perhatikan pada saat pembelajaran di kelas, pesertadidik sering ribut dan mengganggu temannya pada saat berdoa, dan pada saat pelaksanaan praktek sholat di musollah, guru terkadang mengalami kesulitan karena kurangnya gum pembantu yang ikut mengawasi peserta didiknya (Rudi Yunus, Wawancara, Rabu, 06 Februari 2017).
\end{abstract}

Dari penjelasan yang dikemukakan oleh beliau, menurut pemahaman saya kurangnya perhatian peserta didik terhadap pelajaran Pendidikan Agama Islam sehingga peserta didik belum memahami pentingnya pengetahuan tentang agama.

\section{Upaya Yang Dilakukan Kepala Sekolah, Guru Wali Kelas dan Guru BK Mengatasi Kendala Dalam Pembinaan Karakter Peserta Didik Di SMK Negeri Labuang.}

Dalam hal ini kepemimpinan yang demokratis dipraktekkan kepala sekolah SMK Negeri Labuangmelalui kerja sama dengan guru - guru serta orang tua peserta didik untuk membentuk karakter peserta didiknya. Bentuk bimbingan yang ditekankan, menurut beliau selaku kepala sekolah SMK Negeri Labuang yaitu: 
Pengalaman langsung merupakan pengalaman yang diperoleh peserta didik menggunakan semua inderanya, yaitu melihat, menyentuh, mendengar, dan merasa. Melalui pengalaman langsung peserta didik dapat membentuk karakternya, mengembangkan keterampilannya, mengamati, membandingkan, menghitung, dan mengemukakan pendapatnya. Misalnya pada kegiatan praktek kerja lapangan peserta didik mampu bekerja sama dengan perusahaan (Rudi Yunus, Wawancara, Rabu, 06 Februari 2017).

Dari penjelasan yang dikemukakan oleh beliau, menurut pemahaman saya bahwa salah satu upaya yang dilakukan kepala sekolah dalam pembentukan karakter peserta didiknya adalah menyediakan pengalaman langsung kepada peserta didiknya seperti praktek kerja lapangan dimana semua peserta didik wajib mengikuti prakerin (praktek kerja industri) agar teori yang dipelajari disekolah bisa dipraktekkan langsung diperusahaan yang bekerja sama dengan sekolah, dimana peserta didik mampu mengembangkan keterampilannya di perusahaan yang telah ditentukan oleh sekolah.

\section{KESIMPULAN}

Adapun kesimpulan yang diperoleh berdasarkan hasil penelitian tentang Model Kepemimpinan Dalam Penelitian Karakter Peserta Didik di SMK Negeri Labuang Kabupaten Polewali Mandar, yaitu:

1. Bapak Rudi Yunus, S.Pd. M.Pd., selaku kepala sekolah SMK Negeri Labuang, yang menganut model kepemimpinan demokratis dan sesekali otoriter dan Sudan diterapkan secara profesional dan optimal. Selain mampu mengoperasionalkan peran, fungsi, serta tanggung jawab, tolak ukur penilaian keberhasilan kepemimpinan yang lain adalah model kepemimpinan yang digunakan. Model kepemimpinan demokratis tetap diprioritaskan sebagai dasar dalam memutuskan setiap kebijakan yang dibuat.

2. Kepemimpinan demokratis yang diterapkan oleh Bapak Rudi Yunus, S.Pd. M.Pd. selaku kepala sekolah SMK Negeri Labuang sangat mempengaruhi dalam pembentukan karakter peserta didik. Dengan adanya kerja sama antara guru-guru dan guru BK dalam pembinaan karakter peserta didik, guna membentuk perilaku sesuai dengan ajaran agama yang dianut, mengembangkan diri dengan memanfaatkan kelebihan diri serta memperbaiki kekurangannya, menunjukan sikap percaya diri, bertanggung jawab atas perilaku, perbuatan, dan pekerjaannya, berpartisipasi dalam kehidupan masyarakat, berbangsa, dan bernegara secara demokratis, sertamenguasai kompetensi program keahlian dan kewirausahaan baik untuk memenuhi tuntutan dunia kerja maupun untuk mengikuti pendidikan tinggi sesuai dengan kejuruannya. 


\section{DAFTAR PUSTAKA}

Arikunto, Suharsimi. Prosedur Penelitian Suatu Pendekatan Praktik. Jakarta: PT Rineka Cipta, 2010.

Creswell, John W., Reserach Design, diterjemahkan dengan Judul Metode Kualitatif, Kuantitatif dan Mix. (Get. HI. Yogyakarta: Pustaka Pelajar, 2010).

Danim, Sudarwan dan Suparno. Manajemen dan Kepemimpinan Transformasional Kepala Sekolah. Jakarta: PT. Rineka Cipta, 2008

Danim, Sudarwan. Menjadi Peneliti Kualitatif. Bandung: Pustaka Setia, 2002.

Gunawan, Ary H. Administrasi Sekolah (Administrasi Pendidikan Mikro), (Jakarta: PT Rineka Cipta).

Gunawan, Ary H. Sosiologi Pendidikan: Suatu Analisis Sosiologi tentang Pelbagai Problem Pendidikan (Jakarta: Rineka Cipta; 2000).

Gunawan, Heri. Pendidikan karakter: Implementasi Pendidikan Karakter Melalui Intergrasi Dalam Pembinaan Kesiswaan. Bandung: Penerbit Alfabeta, 2012.

Moleong, Lexy J. Metodologi Penelitian Kualitatif (Bandung, Remaja Rosdakarya, 2002).

Mukhtar. Desain Pembelajaran Pendidikan Agama Islam. Jakarta: Misaka Galiza, 2003.

Munir, Abdullah. Pendidikan Karakter. Bandung: Penerbit Pedagogia, 2010.

Purwanto dan Djojopranoto. Pendidikan Karakter Konsep dan Implementasi. Bandung: Penerbit Alfabeta 1996.

Putra, Nusa dan Ninin Dwilestari. Penelitian Kualitatif Pendidikan Anak Usia Dini. Jakarta: Rajagrafindo Persada, 2012.

Shaleh, Munawar. Politik Pendidikan: Membangun Sumber Daya Bangsa dengan Peningkatan Kualitas Pendidikan. Jakarta: Grafindo Khazanah IImu, 2005.

Soetopo, Hendiyat dan Wasty, Soemanto. Pengantar Operasional Administrasi Pendidikan Surabaya: Usaha Nasional. 1982.

Sugiyono. "Memahami Penelitian Kualitatif \Bandung: Alfabeta, 2008.

Triagulasi dan Kabsahan Data Dalam Penelitian, http://govang-karawang.com/2010/02/triangulasi dan keabsahan data dalam penelitian/. Di akses pada tanggal 20 Oktober 2015.

Wahab, Abdul Aziz. Anatomi Organisasi dan Kepemimpinan Pendidikan: Telaah Terhadap Organisasi dan Pengelolaan Organisasi Pendidikan. Bandung: Alfabeta, 2008.

Wikipedia bahasa Indonesia, encyclopedia bebas. https://id.wikipedia.org/wiki/ Kepala sekolah.Di akses pada 4 Juni 2016. 